\title{
Tracing and heavenly freedom
}

\author{
Benjamin Matheson ${ }^{1}$
}

Received: 5 May 2017/ Accepted: 23 August 2017/Published online: 1 September 2017

(C) The Author(s) 2017. This article is an open access publication

\begin{abstract}
Accounts of heavenly freedom typically attempt to reconcile the claim that the redeemed have free will with the claim that the redeemed cannot sin. In this paper, I first argue that Pawl and Timpe (Faith Philos 26(4):396-417, 2009) tracing account of heavenly freedom-according to which the redeemed in heaven have only 'derivative' free will-is untenable. I then sketch an alternative account of heavenly freedom, one which eschews derivative free will. On this account, the redeemed are able to sin in heaven.
\end{abstract}

Keywords Heavenly freedom - Free will - Tracing · Heaven · Derivative free will $\cdot$ Significant freedom

\section{Introduction}

Most contemporary accounts of free will and moral responsibility include a tracing component. ${ }^{1}$ Such accounts thus distinguish between direct and derivative free will and moral responsibility. Pawl and Timpe (2009) have recently appealed to tracing in their account of heavenly freedom. They claim that the residents of heaven-the redeemed-have derivative, but not direct, free will. ${ }^{2}$ This tracing account of heavenly freedom aims to avoid the Problem of Heaven Freedom. According to

\footnotetext{
${ }^{1}$ For example, Fischer and Ravizza (1998), Fischer and Tognazzini (2009), McKenna (2012), Nelkin (2011), Vargas (2013), and Hartman (2017).

2 There is a complication with my characterisation here. See fn. 9.

Benjamin Matheson

benjamin.matheson@gu.se

1 University of Gothenburg, Gothenburg, Sweden
} 
Pawl and Timpe, this problem results from the traditional view of heaven that they claim entails the following two propositions:

1. the redeemed in heaven have free will, and

2. the redeemed in heaven are no longer capable of sinning (2009: 397$)^{3}$

The problem is that these two propositions seem to contradict each other. If (1) is true, then it seems that (2) must be false. That is to say, if a person has free will then this seems to entail that she is capable of sinning (e.g., performing a morally wrong action). And if a person is incapable of sinning, then it seems she lacks free will. But this all depends on what account of free will one endorses, and Pawl and Timpe claim to solve the Problem of Heavenly Freedom by endorsing an account that says that the redeemed have derivative free will. In this paper, I argue that Pawl and Timpe's tracing account of heavenly freedom is untenable. ${ }^{4}$ To understand Pawl and Timpe's response, it is necessary to explain the background of this debate.

Broadly speaking, there are two options when it comes to an account of free will and moral responsibility: compatibilism and libertarianism. According the former, free will is compatible with the truth of causal determinism (the thesis that all facts about the future are entailed by the conjunction of all facts about the past and the laws of nature) and theological determinism (the thesis that every event stems directly from God's will). According to the latter, free will requires the falsity of causal and theological determinism. Given that causal determinism and theological determinism each entail that there is only physically possible future, it seems that compatibilism entails that a person can never act other than they actually do. So persons with compatibilist free will have only one possible path ahead of them; there are no alternative routes to take. Libertarians reject this view; they hold that being causally or theologically determined is freedom-undermining. What free will requires, according to the libertarian, is the ability to do otherwise - that is to say, a person must have the power to choose alternative paths through life. ${ }^{5}$

While this is controversial in some circles, it seems that classical theists are forced to accept libertarianism. Why? Well, because it provides the most satisfying response to the logical problem of evil-that is, the problem of reconciling the apparent inconsistency between God's attributes (specifically, omnipotence, omniscience, and moral perfection) and the existence of evil. ${ }^{6}$ Many atheists hold that God's existence and the existence of evil are inconsistent. Given that evil exists, such atheists conclude that God does not. According to the free will defence, however, God's existence is compatible with the existence of evil because God gave

\footnotetext{
3 See Nagasawa et al. (2004) for another expression of this problem.

4 Sennett (1999) also defends a variant of the tracing view, which he calls 'proximate compatibilism'. Pawl and Timpe's view is stronger than Sennett's, so my points will apply a fortiori to Sennett's. Indeed, my argument generalises to all tracing accounts of heavenly freedom.

5 Some libertarians hold that free will and moral responsibility are incompatible with causal determinism but compatible with theological determinism—see, e.g., Hunt (1996). Since these views are not my focus here, I shall set them aside for the sake of simplicity.

${ }^{6}$ Some classical theists are compatibilists, though—e.g., Baker (2003). See also Timpe (2004) for a response to Baker.
} 
persons libertarian free will. According to Plantinga (1974: 29-30), this libertarian free will must be significant. Significant freedom requires that a person be able to perform an action and able to refrain from performing that action, and that the action in question must be morally significantly; an action is morally significant if it would be wrong for [a person] to perform this action but right to refrain or vice versa'. For example, John hitting Brian is morally significant because it is wrong for John to hit Brian and right for John to refrain from hitting Brian. John is significantly free when he hits Brian given John could have refrained from hitting Brian. Given such freedom, it seems possible that evil in the world results from persons rather than from God. But if significant freedom results in evil, then shouldn't God not give persons such freedom? Plantinga's (1974: 30) answer is that it is better for God to give persons such freedom than for him not to. This is because, as Plantinga stipulates, significant freedom is intrinsically valuable. It follows that it is possible for God and evil to co-exist, which thus undercuts the logical problem of evil.

Compatibilist free will just doesn't seem to cut the mustard, unfortunately. According to compatibilism, all free actions are either the result of causal or theological determination; either way (given that God either created the initial conditions of the universe or willed each and every event to occur) God is the ultimate source of evil in the world; but given that God is morally perfect, he cannot be the ultimate source of evil. So the compatibilist free will defence fails.

But significant freedom seems to conflict with another part of the classical theist's world view. ${ }^{7}$ This is her belief that at least certain persons will enjoy an eternity in blissful communion with God in heaven. But since classical theists seem committed to holding that persons have significant freedom, this seems to require that the redeemed are able to sin. But if this is true then (2) is false, and so the traditional view of heaven is false.

Pawl and Timpe's tracing view of heavenly freedom attempts to avoid this implication. According to their view, the redeemed have free will yet they cannot sin-in other words, the redeemed lack significant freedom but they still have free will, in an important sense. Pawl and Timpe do not reject the notion of significant freedom; they acknowledge it plays a crucial role in undermining the logical problem of evil (Pawl and Timpe 2009: 399). Rather, they argue that significant freedom is only necessary at certain points in a person's life. The idea is that the redeemed's free will can be traced back to or derives from a person's earlier and significantly-and thus directly-free actions. These earlier significantly free actions can thereby set a person's moral character a particular way. The result is that the redeemed have set morally good characters and so are unable to $\sin ^{8}$ That is to say, the redeemed are derivatively free. Prior to being redeemed, however, such persons had the ability to sin for at least a portion of their ante-redemption

\footnotetext{
7 The following is not entailed by classical theism. One could be a classical theist and reject view that certain persons will enjoy an eternity in heaven with God. However, this is a major part of most classical theisms, such as Christianity, and most classical theists subscribe to this further view.

${ }^{8}$ Pawl and Timpe (2009: 409) construct their view such that they redeemed can still choose between morally good options. Cowan (2011) objects to this point. See Pawl and Timpe (2013) for a response. I mostly set aside this issue in what follows, though see fn. 9.
} 
existence. Persons with the ability to sin are directly free which is equivalent to being significantly free. ${ }^{9}$

While the tracing view is a prima facie plausible account of heavenly freedom, in this paper I shall argue that it is untenable. The points I make do not just undermine Pawl and Timpe's account of heavenly freedom; rather, they teach us some important lessons about the nature of free will. I have two main points, one weaker and the other stronger. The weaker point challenges the plausibility of the notion of 'derivative free will'. I argue that while there are independent reasons to hold that derivative moral responsibility is coherent concept, there aren't such reasons in favour of derivative free will being a coherent concept. The stronger point concerns character setting. I argue that being able to change one's mind is at least partly constitutive of significant freedom's value. However, once one's character is set, one loses the freedom to change one's mind. Hence, if a person sets her character she undermines the value of her previously having had significant freedom. I argue that this is sufficient ground to reject tracing view of heavenly freedom. Finally, I argue that the only plausible account of heavenly freedom is one which maintains that the redeemed are significantly free. This, of course, requires rejecting the traditional view of heaven. However, I note that this accords with one understanding of another part of Christian theology—namely The Fall of Lucifer. I consider Timpe's (2014) recent account of The Fall, and I argue that he cannot rule out the possibility of the redeemed sinning. So, despite its problems, the best account of heavenly freedom entails redemption is not necessarily permanent.

\footnotetext{
9 There is a complication here. Pawl and Timpe (2009: 408) claim that the redeemed, on their view, have 'non-derivative freedom' - that is, the redeemed have direct free will in heaven. However, they claim that the redeemed lack significant freedom-that is, the redeemed cannot sin. What they mean, as I discuss later, is that the redeemed are not determined by their characters to perform particular actions; rather, the redeemed are determined, by their earlier significantly free actions, not to sin. So the redeemed can still choose between a range of good courses of action (e.g., singing, dancing, or whatever happens in heaven). But it seems that simply being able to choose between good courses of action means that the redeemed are not directly free. That is, direct freedom is synonymous with significant freedom—at least that is what defenders of the free will defence should say. This is really only a terminological quibble, and nothing of substance hangs on it. Readers should simply bear in mind that when I say that the redeemed are derivatively free this only means that they cannot sin, and not that they lack the general ability to choose between different (good) courses of action.

It's worth noting that Pawl and Timpe's view actually has two tracing components: one between derivative and direct (in their sense; what they call 'non-derivative') free will, and another between direct (in their sense) and significant freedom. Thus, on their view, direct free will (choosing between exclusively good options or between exclusively bad options) is derived from significant freedom (choosing between good or bad options). To keep things simple, I have stuck with (what I contend) is the more plausible view of equating direct free will and significant freedom. Any alleged freedom that is derived from significant freedom is what I shall call 'derivative free will' because, as all parties ultimately agree, it is derived from significantly free actions.
} 


\section{Derivative free will}

Tracing seems essential to an account of moral responsibility because it seems to solve a puzzle for the basic control account of responsibility. The basic control account says that there is a freedom and an epistemic condition on being morally responsible. On the basic control account, then, an agent is morally responsible for an action $A$ if and only if she satisfies the freedom and the epistemic condition. Let's suppose that the freedom condition is exercising significant freedom, and that the epistemic condition is knowing the moral status of one's action. ${ }^{10}$ On this view, then, an agent is morally responsible for some action $A$ if and only if she exercises significant freedom and she knows the moral status of $A$.

The basic control account certainly seems plausible. It explains attributions of moral responsibility in a lot of cases. However, there are counter-examples to the basic control account, the most obvious of which are intoxication cases. Suppose an agent-call her Sally-freely gets (that is, she exercises significant freedom in getting) blind drunk knowing she might do something reckless when she is drunk. She then drunkenly hits a child while driving her car. Is Sally morally responsible for hitting the child? It seems that she is: she got drunk freely and she knew that getting drunk might cause her to act recklessly; in this case, it resulted in her injuring a child. This case is therefore a counter-example to the basic control account. When she hits the child, Sally does not satisfy the conditions of the basic control account; because she is blind drunk, she seems to lack control-and hence free will-over her action at that time (and she plausibly is not aware the moral status of her action at that time either).

So the basic control account must (at least) be modified. The modification it requires should be clear: we must include a tracing component in our account of moral responsibility. The reason that Sally seems morally responsible for hitting the child is because that action stems from an earlier action that Sally performed freely, and when she performed that action Sally could foresee she would perform an action of that type she later performed (i.e. a reckless action). In other words, Sally's morally responsibility derives from or traces back to an earlier action that she was directly morally responsible for. Sally is therefore derivatively morally responsible for hitting the child.

While it makes sense to say that Sally is derivatively morally responsible for hitting the child, it's not clear it makes sense to say that Sally acts freely in hitting the child. That is, does it make sense to say that Sally has derivative free will? I don't think so. The whole point of appealing to tracing here is because Sally seems morally responsible even though she lacks control over her actions, and if she lacks control then she lacks free will.

Of course, one might point to the difference between direct ${ }^{11}$ free will and derivative free will, with only the former requiring control or the ability to do

\footnotetext{
10 These claims may be controversial in some circles. But I take it that within a debate between those who accept that significant freedom is necessary to avoid the logical problem of evil that these are not controversial assumptions.

11 To be clear, not all those who endorse the distinction between direct and derivative free will hold that direct free will is synonymous with significant free will. Many compatibilists endorse this distinction and
} 
morally otherwise-i.e. significant freedom-at the time of action and the latter not requiring these things at the time of action. But this doesn't help. All this does is label things in a strange away. It seems that any free will worthy of the name is one that promises the agent control over her actions-i.e. the ability do morally other than she actually does, i.e. significant freedom. Drunken Sally lacks the ability to do otherwise when she acts, and so she seems to lack free will (whilst she remains blind drunk).

My point here is against the coherence of the concept of 'derivative free will'. If it holds, then tracing accounts of heavenly freedom fail: if the redeemed lack the ability to do otherwise, then they lack free will. Pawl and Timpe (2009: 408) might point out that the redeemed can do otherwise on their view. On their view, the redeemed are not determined by their earlier characters to perform the actions they perform; rather, a redeemed person's character is such that she cannot sin. But this is compatible with the redeemed choosing between good options: a redeemed person might choose between singing in a heavenly choir or dancing. However, this is a thin sense of 'could have done otherwise'. It's true that the redeemed can choose between some options, but they cannot choose between good and bad options- that is, they still lack significant freedom. Indeed, it is plausible that Drunken Sally retains the ability to choose between bad options: she might have driven faster and injured the child more; that option still seems open to her even in her state of blind drunkenness. The reason she seems to lack control is because she cannot alter her trajectory from a bad course of action to a good course of action. ${ }^{12}$ This is equally true for the redeemed on Timpe and Pawl's view: they cannot alter their trajectory from the good to the bad. So, just as it seems odd to say that Drunken Sally exercises free will, it seems odd to say that the redeemed exercise free will. Hence the concept of 'derivative free will' seems, at least, suspect.

I don't expect this point to convince those who already endorse the notion of 'derivative free will'. They might point out that cases of Drunken Sally and the redeemed aren't quite analogous. They might instead claim that the redeemed are more like Martin Luther when he claimed that he could 'do no other' than hammer his theses to the church door to initiate the reformation. This case is used by Dennett (1983: 133) in an effort to show that we don't really care about whether an agent has alternative possibilities in our attributions of moral responsibility; as Dennett sees it, Luther is morally responsible even if he couldn't have done otherwise than he did. Pawl and Timpe (and others who endorse the notion of derivative freedom) could claim that Luther could have done otherwise-e.g., he could have started the reformation the day before or the day after, or he could have hammered the theses on different part of the door or a different part of the church. However, because of his earlier exercises of significant freedom, Luther set his character such that he

Footnote 11 continued

they reject the claim that significant freedom is necessary for free will and/or moral responsibility. See, for example, Fischer and Ravizza (1998: 48-50). But, as noted earlier, I am equating direct and significant freedom here since classical theists are required to endorse significant freedom in order to defend themselves from the logical problem of evil.

12 Indeed, Hanna Pickard (2015) has recently argued that in many cases of apparent compulsion (such as drug addiction) agents retain the ability to do otherwise. 
couldn't but start the reformation. And it perhaps seems plausible that Luther has some sort of freedom when he acts. This could, then, be taken as evidence that the notion of 'derivative free will' is not suspect.

But there is a problem with the Luther case, one which suggests he doesn't in fact lack significant freedom. I think it seems like Luther has some sort of freedom because it seems plausible that he has significant freedom. While Luther claims he can do no other, there are lots of cases where people claim that they cannot do otherwise, when in fact it is plausible that they can do otherwise. These cases are typically ones in which the person is simply expressing how strongly they feel about the cause they are acting on behalf of, and they are not expressing a judgement about their ability to choose between good and bad courses of action. For example, a vegetarian who says they cannot eat meat isn't necessarily saying they literally cannot eat meat; rather, they are simply expressing how strongly they feel about vegetarianism. The same could be true with Luther: he might not be expressing a judgement about his abilities, but rather expressing how strongly he feels about the need for the reformation.

Again, I don't expect those committed to the notion of 'derivative free will' to be convinced. But I think those who are not committed to that notion will see that there is something suspect about the notion of 'derivative free will'. Given this, those people should see something suspect about the tracing account of heavenly freedom.

I think there is an argument against the tracing view of heavenly freedom that even its proponents cannot ignore. In the next section, I develop this argument; it concludes that tracing account of heavenly freedom must be rejected.

\section{Changing your mind}

The lynchpin of the free will defence to the logical problem of evil is the claim that significant freedom is intrinsically valuable. If free will were not valuable, then it would be better, all things considered, for God to not give persons free will since it inevitably leads to evil. But is it true that free will intrinsically valuable-that is, valuable in and of itself? I will argue it is not. Instead, I propose that the reason why significant freedom is valuable is that it allows persons to make up their own minds. God grants persons significant freedom and this allows persons to decide what they are going to do and who they are going to be. If God didn't give people the freedom to make up their own minds, then persons would not be responsible for evil in the world; if persons are not responsible for evil in the world then it seems God must be, and that would render classical theism inconsistent.

Putting the value of free will in terms of 'making up your own mind' might seem to play into Pawl and Timpe's hands. They contend that persons can use significant freedom to set their characters such that they can no longer sin; what is distinctive about the redeemed, on their view, is that they cannot sin because they have set their characters such that sinning is not an option for them. The fact that persons can make up their own minds seems to be synonymous with setting one's character: that is, when a person makes up her mind she has, in effect, set her character. But this isn't so. 
I will now make two comparisons between political freedom and free will to support the claim that making up one's mind is not synonymous with setting one's character. What will come out of these comparisons is that significant freedom is not valuable simply in virtue of allowing persons to make up their minds, but rather in virtue of allowing persons to make up their minds and then to change their minds at later times. Hence a person making up her mind doesn't amount to her setting her character because character setting precludes that person being able to change her mind later on-that is, once a person sets her character, she is no longer free to change her mind.

First, consider slave contracts. A slave contract is one which when a person enters into it, she thereby gives up her rights. The person, in effect, lets herself become the property of some other person; she who enters into a slave contract agrees to become another person's slave. But a person does not have the political freedom to enter into a slave contract. No one is free to enslave a person, not even the person herself.

Second, what is valuable about democracy is that it allows the people to choose who is going to govern them. That is, it gives people the political freedom to make up their own minds about who going to govern them. It is not, however, possible on a democratic model of government for the people to decide at a particular time to always be governed be a particular leader or political party. In countries where this happens - that is, countries that are officially democratic, but which are not in reality democratic - it seems that the people lack the sort of freedom that people in properly democratic countries have.

One reason that slave contracts seem bad is because they stop a person being able to change their mind. One reason that democracy seems valuable is because it ensures that people can later change their minds. While slave contracts undermine political freedom, democracy promotes it. This suggests that being able to change one's mind is necessary for political freedom to be valuable. Just as being able to change one's mind is necessary for political freedom to be valuable, I contend that it is necessary for free will to be valuable too.

But according to Pawl and Timpe (and any proponent of the tracing view of heavenly freedom) the redeemed are unable to change their minds. They can, of course, decide between varying good options. But they cannot choose between a good and an evil path; thus they lack the ability to significantly or morally change their minds. I submit that the value of making up one's mind is, in fact, dependent on one being able to change one's mind at a later time. Consider democracy again. We make up our minds when we vote for a particular candidate/political party. But if voting for that candidate/party resulted in us losing the freedom to vote or to vote for someone else at the next election-that is, if it resulted in us being unable to change our minds (politically speaking) — then whatever prima facie value our freedom to vote for the candidate/party had would be undermined. So, the value of politically making up one's mind is dependent on being able to politically change one's mind later on. These cases suggest that value of significant freedom is dependent on a person being able to change her mind, and this requires that a person can never truly set her character. It must always be possible for person to choose 
between good and evil courses of action if she is to have the sort of freedom that is valuable. So, while significant free will is valuable, it is not intrinsically valuable.

If I'm correct, then the redeemed not only lack the sort of freedom that is valuable whilst they are redeemed, their irreversible loss of significant freedom actually undermines whatever value their earlier exercises of significant freedom prima facie had. This is because they are unable to change their minds, and so they are in an analogous situation to the voters who voted for a party or candidate who then undermined their right to change their (political) minds.

This leads to two problems. First, we would expect the redeemed to have at least had at some point in their lives the sort of freedom that is valuable. But Pawl and Timpe's view, as I've argued, rules that the redeemed have never had such valuable freedom. This might be enough to render Pawl and Timpe's view untenable. It seems clear that heaven is the greatest possible 'place'. Given that heaven is the greatest possible place, we would expect its residents to have at least had the most valuable form of freedom. If redeemed have not at least had the most valuable form of freedom, then heaven is not the greatest possible place. This seems to be an implication that most theists cannot accept.

Second, this doesn't just suggest that the redeemed have not exercised a valuable sort of freedom, it also threatens to undermine the free will defence. Remember that the lynchpin of the free will defence is that free will is valuable: it's better for God, all things considered, to give persons free will than it is for him not to give person's free will. I have argued that significant freedom is not valuable when it leads to persons being unable to change their minds. On Pawl and Timpe's view, the redeemed in heaven have not had, and do not have, the sort of freedom that is valuable; they lost that by exercising significant freedom to set their characters such that they could not change their minds. This implies that the damned - that is, the residents of hell-also lack and have always lacked the sort of freedom that is valuable because they have set their characters such that they perform exclusively bad actions. The upshot is that, on a tracing view of heavenly (and hellish) freedom, no one exercises a valuable sort of freedom because all persons will eventually set their characters, and thereby undermine whatever value their significantly free actions had. This, in turn, undermines the free will defence: it now seems that it is not the case that God providing persons with significant freedom is better than him not giving persons significant freedom (by, say, creating a world without evil), since all persons, on the tracing view, will set their characters eventually, thereby undermining the value significant freedom has. So, it seems that endorsing Pawl and Timpe's account of heavenly freedom requires rejecting the free will defence. I take it that this is not a palatable option for classical theists. Therefore, Pawl and Timpe's - and the tracing view of heavenly freedom, more generally_must be rejected.

\section{Saving heavenly freedom}

The tracing view of heavenly freedom is untenable. Is there another account of heavenly freedom on the table? In this section, I shall propose one. This one will maintain the free will defence and also maintain one thesis of the traditional view of heaven-namely that the redeemed have free will. 
The tracing view of heavenly freedom failed because it required the redeemed to lack significant freedom in heaven. I suggest, instead, that the redeemed retain significant freedom in heaven. Of course, this is in tension with the second thesis of the traditional view of heaven - namely that the redeemed are incapable of sinning. I accept this. The model of heavenly freedom I shall propose explicitly rejects this aspect of the traditional view. This might offend some classical theists' theological temperaments. But there's a theological reason to reject the traditional view in any case-viz. The Fall of Lucifer (at least on one, albeit a controversial, reading of this case).

Lucifer was an angel until he decided to turn against God. A heavenly war ensued and, eventually, the archangel Michael expelled Lucifer from heaven. The story of Lucifer requires that we accept the possibility of heavenly sin. If Lucifer could not have sinned, then he could never have turned away from God. Since he did turn away from God, he could sin. So we have one example of a heavenly sin. All that happened when Lucifer sinned was that he was expelled from heaven. This, I submit, is what would happen to a person who sinned in heaven; they would be expelled from heaven. This helps to explain how the redeemed retain significant freedom without appealing to tracing or derivative free will. This explicitly rejects what Pawl and Timpe call 'the traditional view'. But it, in turn, helps to make sense of the Lucifer's heavenly sin—that is, the primal sin-which explains why evil entered into the world.

I think Timpe's (2014) own account of primal sin suggests the possibility of a heavenly sin analogous to the primal $\sin .{ }^{13}$ Timpe would deny this, of course. But, as I shall now argue, his view seems unable to rule out the possibility of heavenly sin.

Timpe (2014: 14-15) holds that there are four stages of our relationship with God:

- Before the Fall (status integritatis)

- As Fallen (status corruptionis)

- Under Grace (status gratiae)

- In Glory (status gloraie)

So, on Timpe's view, the reason Lucifer could sin is because he was in status integritatis; whereas because the redeemed are in status gloraie, they cannot sin. Timpe finds both Rogers' (2008) voluntarist and MacDonald's (1998) intellectual accounts of primal sin wanting because they leave it unexplained and, moreover, inexplicable how Lucifer sinned-that is, how evil entered into the world. I agree with Timpe. But Timpe doesn't have a better account to offer. Rather, he simply accepts that, "a Christian account of primal sin cannot avoid all arbitrariness", and then tries to render this position more palatable by saying, "Whether or not this amounts to an insurmountable objection to the philosophical respectable of Christian accounts of free will and sin will depend, among other things, on the positive merits that those accounts can offer" (2014: 48).

$\overline{13}$ I originally suggest this point in Matheson (2017). I draw on that in what follows. 
The problem for Timpe is that he leaves primal sin unexplained. Thus how or why primal sin occurred remains a mystery. Moreover, Timpe seems to accept that it is (perhaps in principle) inexplicable. Thus he seems to accept that primal sin is always going to be mystery. The trouble with mysteries is that they can pop up elsewhere. If something mysterious or inexplicable occurs at $t_{1}$, then what's to stop the same mysterious or inexplicable thing occurring at $t_{2}$ ? Given that the mystery cannot, perhaps in principle, be explained, there's nothing a priori that can rule that mystery occurring at another time or elsewhere. Because primal sin is left mysterious and inexplicable, the possibility of a mysterious and inexplicable heavenly sin hasn't been ruled out. Timpe might contend that they have set their characters such that they cannot sin. But mysteries and the inexplicable can just happen; they are, after all, mysterious and inexplicable.

It makes no difference that the redeemed are in a different stage of their relationship with God; again, mysteries and the inexplicable can just happen-that's what makes them mysterious and inexplicable! So, the problem can't be avoided by simply labelling the stages that people are at in their relationship with God, and that seems to be all Timpe has at this point. Consider an analogy. We know that old people can't grow new teeth. But suppose it were mysterious and inexplicable how babies grew teeth. If this were true, we wouldn't be able to rule out old people growing new teeth; after all, the process by which babies grow teeth is (we have assumed) mysterious and inexplicable, so we can't rule it occurring with old people. It simply doesn't help to point out that babies and old people are at different stages of development.

So, Timpe's account of primal sin also seems in tension with his and Pawl's account of heavenly freedom. If they accept Timpe's account of primal sin, it seems that they cannot accept their own account of heavenly freedom because Timpe's account of primal sin leaves open that there can also be heavenly sin. The account of heavenly freedom that I have sketched is, in fact, supported by this account of primal sin. The Fall of Lucifer gives us good reason to think that heavenly sin is not only possible, but actual.

\section{Conclusion}

In this paper, I have argued that Pawl and Timpe's tracing account of heavenly freedom is untenable. I first argued that there is something suspect about the notion of 'derivative free will'. But I accepted that those already wedded to this notion might not be moved by my considerations. I then argued that what is valuable about free will is the ability to make and change one's mind.

The trouble for Pawl and Timpe is that the redeemed, on their account, lack the ability to change their minds. If the redeemed set their characters such that they cannot change their minds, then they undermine the value of exercising significant freedom in the first place, since if significant freedom is used to set one's character such that one cannot later change one's mind, then this exercise of significant freedom undercuts the value of exercising significant freedom in the first place. This led to two problems. First, it seems that the redeemed should have such valuable 
freedom. Second, it undermines the free will defence, something which all classical theists plausibly must endorse. Finally, I suggested an alternative account of heavenly freedom. On this account, the redeemed retain significant freedom, and if they use that freedom to sin then they are expelled from heaven. So, on this account, the redeemed are capable of sinning.

This might seem in tension with the claim that heaven is the greatest possible place. For surely this implies that it must not be possible to sin in heaven. I'm sensitive to this objection, as I have endorsed the point it expresses elsewhere (see Matheson 2014). But it seems that any account of heavenly freedom must accommodate the primal sin. Since primal sin is mysterious, this leaves open the possibility of an equally mysterious heavenly sin. If correct, this suggests that there is a tension at the heart of Christian theology. Indeed, it might be even be that the concept of heaven itself is incoherent. These are speculations and I won't try to resolve this tension or argue that heaven is an incoherent concept here. Perhaps even on the view I have proposed there is a sense in which the redeemed cannot sin. On my view, the redeemed are expelled from heaven when they sin. But perhaps by sinning a person renders herself non-redeemed; so, there may be a sense in which the redeemed are still unable to sin because sinning automatically changes their ontological status from redeemed to non-redeemed. I'm not convinced by this move, but it remains a possibility for someone who wishes to maintain the traditional view of heaven to develop. I end by simply noting that if this tension can be resolved and so heaven is a coherent concept, then the account of heavenly freedom I have proposed is the most plausible one.

Acknowledgements Thanks to Per Milam, Kyle MacLachlan, Alfred Archer, and Larry Sock for valuable discussion and to an anonymous reviewer for helpful comments.

Open Access This article is distributed under the terms of the Creative Commons Attribution 4.0 International License (http://creativecommons.org/licenses/by/4.0/), which permits unrestricted use, distribution, and reproduction in any medium, provided you give appropriate credit to the original author(s) and the source, provide a link to the Creative Commons license, and indicate if changes were made.

\section{References}

Baker, L. R. (2003). Why Christians should not be libertarians: An Augustinian challenge. Faith and Philosophy, 20, 460-473.

Cowan, S. (2011). Compatibilism and the sinlessness of the redeemed in heaven. Faith and Philosophy, 28(4), 416-437.

Dennett, D. (1983). Elbow room: The varieties of free will worth wanting. Oxford: Oxford University Press.

Fischer, J. M., \& Ravizza, M. (1998). Responsibility and control: A theory of moral responsibility. Cambridge: Cambridge University Press.

Fischer, J. M., \& Tognazzini, N. A. (2009). The truth about tracing. Nô̂s, 43(3), 531-556.

Hartman, R. J. (2017). In defense of moral luck: Why luck often affects praiseworthiness and blameworthiness. New York: Routledge.

Hunt, D. (1996). Frankfurt counterexamples. Faith and Philosophy, 13(3), 395-401.

MacDonald, S. (1998). Primal sin. In G. Matthews (Ed.), The Augustinian tradition. Berkeley, CA: University of California Press. 
Matheson, B. (2014). Escaping heaven. International Journal for Philosophy of Religion, 75(3), 197-206.

Matheson, B. (2017). Kevin Timpe: Free will in philosophical theology. Bloomsbury 2014. European Journal for Philosophy of Religion, 9(1), 212-221.

McKenna, M. (2012). Conversation and responsibility. New York: Oxford University Press.

Nagasawa, Y., Oppy, G., \& Trakakis, N. (2004). Salvation in heaven? Philosophical Papers, 33(1), $97-119$.

Nelkin, D. K. (2011). Making sense of freedom and responsibility. Oxford: Oxford University Press.

Pawl, T., \& Timpe, K. (2009). Incompatibilism, sin, and free will in heaven. Faith and Philosophy, 26(4), $396-417$.

Pawl, T., \& Timpe, K. (2013). Heavenly Freedom: A reply to Cowan. Faith and Philosophy, 30(2), $188-197$.

Pickard, H. (2015). Psychopathology and the ability to do otherwise. Philosophy and Phenomenological Research, 90(1), 135-163.

Plantinga, A. (1974). God, freedom, and evil. Grand Rapids, MI: Eerdmans Publishing.

Rogers, K. (2008). Anselm on freedom. New York, NY: Oxford University Press.

Sennett, J. F. (1999). Is there freedom in heaven? Faith and Philosophy, 16(1), 69-82.

Timpe, K. (2004). Why Christians might be libertarians: A response to Lynne Rudder Baker. Philosophia Christi, 6(2), 279-288.

Timpe, K. (2014). Free will in philosophical theology. London: Bloomsbury.

Vargas, M. (2012). Building better beings: A theory of moral responsibility. Oxford: Oxford University Press. 